\author{
Journal of Current and Advance Medical Research \\ January 2017, Vol. 4, No. 1, pp. 3-12 \\ http://www.banglajol.info/index.php/JCAMR \\ ISSN (Print) 2313-447X
}

ORIGINAL ARTICLE

OPEN 2 ACCESS

\title{
Serum Cystatin C as an Endogenous Marker of Renal Function in Patients with Chronic Kidney Disease (CKD)
}

\author{
Md. Anwarul Haque Faraji ${ }^{1}$, Mohammed Rashed Anwar ${ }^{2}$, Dilip Kumar Debnath ${ }^{3}$, \\ Md. Babrul Alam ${ }^{4}$, Syed Mahbub Morshed ${ }^{5}$, Kam Mahbub Hasan ${ }^{6}$
}

\begin{abstract}
${ }^{1}$ Assistant Professor, Department of Nephrology, National Institute of Kidney Diseases \& Urology, Dhaka, Bangladesh; ${ }^{2}$ Assistant Professor, Department of Nephrology, National Institute of Kidney Diseases \& urology, Dhaka, Bangladesh; ${ }^{3}$ Assistant Professor, Department of Nephrology, National Institute of Kidney Diseases \& Urology, Dhaka, Bangladesh; ${ }^{4}$ Associate Professor, Department of Nephrology, National Institute of Kidney Diseases \& urology, Dhaka, Bangladesh; ${ }^{5}$ Assistant Professor, Department of Nephrology, Shaheed Suhrawardy medical College, Dhaka, Bangladesh; ${ }^{6}$ Medical Officer, Department of Cardiology, National Institute of Cardiovascular Diseases, Dhaka, Bangladesh
\end{abstract}

[Reviewed: 30 August 2016; Accepted on: 1 November 2016; Published on: 1 January 2017]

\section{Abstract}

Background: Cystatin $\mathrm{C}$ is being considered as a potential replacement for serum creatinine as a filtration marker. Objectives: This present study was conducted to determine the validity of Cystatin $\mathrm{C}$ as a renal function test and to compare the Cystatin $\mathrm{C}$ and serum creatinine level between the CKD cases and person not having CKD. Methodology: The present case control study was conducted in the department of Nephrology of Dhaka Medical College Hospital during the period of January 2009 to December 2009 with the aim to find out the serum Cystatin $\mathrm{C}$ as diagnostic markers of chronic kidney disease. In the present study total 100 respondents were included. Among them 50 were CKD patients and another 50 were without CKD. Results: It was an age and sex matched study. Out of 50 patients with CKD, 29 (58.0\%) were in the stage IV followed by $15(30.0 \%)$ were in the stage III and rest $6(12.0 \%)$ were in the stage V. In CKD group 31 (62.0\%) had glomerulonephritis, 18 (36.0\%) had HTN, $11(22.0 \%)$ had DM and $3(6.0 \%)$ had obstructive uropathy. In without CKD group $9(18.0 \%)$ had HTN, $6(12.0 \%)$ had DM. Mean \pm SD of Serum Creatinine in CKD and without CKD groups were $5.73 \pm 2.69$ and $0.85 \pm 0.11 \mathrm{mg} / \mathrm{dl} \mathrm{respectively}$. Mean \pm SD of Serum Cystatin C in CKD and without CKD groups were 3.59 \pm 1.21 and $0.71 \pm 0.09 \mathrm{mg} / \mathrm{dl}$ respectively. In all patients sensitivity of Cystatin $\mathrm{C}$ to diagnose CKD was $100.0 \%$ and specificity also100.0\%. Sensitivity of serum creatinine to diagnose CKD was $88.0 \%$ and specificity was $100.0 \%$. Conclusions: Cystatin $\mathrm{C}$ proved more reliable than creatinine and was comparable to plasma creatinine and Cockcroft-Gault estimation. Serum Cystatin C had higher diagnostic accuracy with high sensitivity and specificity to detect renal function and is a reliable marker of renal function. [Journal of Current and Advance Medical Research 2017;4(1):3-12]

Keywords: Cystatin C; CKD; Endogenous Marker; Renal Function

Correspondence: Dr. Md. Anwarul Haque Faraji, Assistant Professor, Department of Nephrology, National Institute of Kidney Diseases \& Urology, Dhaka, Bangladesh; Email: anwar_faraji@ yahoo.com; Cell no.: +8801552306831

Cite this article as: Faraji MAH, Anwar MR, Debnath DK, Alam MB, Morshed SM, Hasan KAMM. Serum Cystatin C as an Endogenous Marker of Renal Function in Patients with Chronic Kidney Disease (CKD). Journal of Current and Advance Medical Research 2017;4(1):3-12

Conflict of Interest: All the authors have declared that there was no conflict of interest.

Funding: This research project was not funded by any group or any institute on.

Contributions to authors: MAHF, MRA \& DKD have contributed in protocol preparation up to surgical procedures as well as the report writing; furthermore, MAHF, MBA, SMM and KAMMH have written the manuscript and have revised the manuscript. Copyright: @2017 Sharif et al. Published by Journal of Current and Advance Medical Research. This article is published under the Creative Commons CC BY-NC License (https://creativecommons.org/licenses/by-nc/4.0/). This license permits use, distribution and reproduction in any medium, provided the original work is properly cited, and is not used for commercial purposes. 


\section{Introduction}

Chronic kidney disease (CKD) is now recognized as one of the leading causes of disease burden globally $^{1}$ and it refers to an irreversible deterioration in renal function which classically develops over a period of years ${ }^{2,3}$. It is a severe condition that reduces life expectancy and typically progresses to end-stage renal disease (ESRD) and a need for renal replacement therapy ${ }^{4}$. Initially, it is manifested only as a biochemical abnormality. Eventually, loss of the excretory, metabolic and endocrine functions of the kidney leads to the development of the clinical symptoms and signs of renal failure, which are referred to as uraemia. The social and economic consequences of CKD are considerable ${ }^{5}$. Biochemical markers play an important role in accurate diagnosis and also for assessing risk and adopting therapy that improves clinical outcome. Over decades research and utilization of biomarkers has evolved substantially ${ }^{6}$. As markers of renal function creatinine, urea, uric acid and electrolytes are for routine analysis whereas several studies have confirmed and consolidated the usefulness of markers such as Cystatin C, $\beta$-Trace Protein ${ }^{6}$.

Glomerular filtration rate (GFR) is an important indicator of kidney function, critical for detection, evaluation and management of CKD. GFR cannot be practically measured for routine clinical or research purposes and therefore, serum creatinine is often used to estimate GFR. Several factors affect the level of serum creatinine other than GFR, including its generation from muscle metabolism. GFR estimating equations, such as the Modification of Diet in Renal Disease (MDRD) Study equation, include age, sex, and race to account for the average differences in muscle mass among subgroups; however, the magnitude of the association of muscle mass with age, sex, and race vary among populations, compromising the generalizability of the equations. Furthermore, incorporation of age, sex and race in the estimating equation does not account for variation in creatinine generation due to diet or other clinical conditions, such as illnesses complicated by malnutrition, inflammation or deconditioning, that also affect muscle mass. These other causes of creatinine generation lead to imprecision in the estimates. Cystatin $\mathrm{C}$ is being considered as a potential replacement for serum creatinine as a filtration marker. Most studies show that serum levels of Cystatin C (Scys) are more closely correlated with GFR than serum creatinine $(\mathrm{Scr})^{7}$. Serum Cystatin $\mathrm{C}$ has been proposed as a new endogenous marker of GFR. Analysis of correlations and diagnostic accuracy of different
GFR markers indicate that serum Cystatin $\mathrm{C}$ is a more reliable marker of GFR in patients with CKD than serum creatinine ${ }^{8}$. Plasma Cystatin $\mathrm{C}$ is an emerging parameter to assess kidney function ${ }^{9}$.

Cystatin C (Cyst C), a low molecular weight protein freely filtered through the glomerulus, and almost completely reabsorbed and catabolized by tubular cells, has been proposed as a new and very sensitive serum marker of change in $\mathrm{GFR}^{10}$. By comparing GFR (determined with 51Cr-EDTA) of Cystatin C and creatinine, Cystatin $\mathrm{C}$ was found to be superior to creatinine as an indicator of GFR since the serum creatinine concentration changes significantly only when GFR is already impaired by $50 \%$. Cystatin C serum concentration is mainly determined by GFR. Combined measurement of Cystatin $\mathrm{C}$ serum concentration and its excretion in urine is useful in assessing early decrease of GFR and proximal tubule damage ${ }^{11}$. Epidemiological studies have shown, based on equations derived from creatinine, that Cystatin $\mathrm{C}$ is better than creatinine or glomerular filtrate as a predictive factor for cardiovascular morbidity and mortality, especially in elderly patients and in the general population with no known CKD. There has also been recent evidence that Cystatin $\mathrm{C}$ is associated to global and cardiovascular mortality in nondiabetic patients with stage 3-4 CKD ${ }^{12}$. Cystatin C (Cyst C) freely filtered through the glomerulus, and almost completely reabsorbed and catabolized by tubular cells, has been proposed as a new and very sensitive serum marker of change in GFR ${ }^{10}$. Serum Cystatin $\mathrm{C}$ measurement offers a simpler and more sensitive screening test than serum creatinine for early changes in GFR ${ }^{13}$. The simplicity of serum Cystatin $\mathrm{C}$ detection and its reasonable cost suggest that this test may soon replace $\mathrm{Ccr}$ as the biochemical marker of choice for monitoring GFR in routine practice. The present case control study was conducted in the department of Nephrology of Dhaka Medical College Hospital with the aim to find out the serum Cystatin $\mathrm{C}$ as diagnostic markers of chronic kidney disease.

\section{Methodology}

This present case control study conducted in the Department of Nephrology, Dhaka Medical College and Hospital $(\mathrm{DMCH})$, Dhaka during the period of January 2009 to December 2009. Purposively selected participants were included in the study, among them CKD patients were included in the study as cases and patients with age and sex matched without CKD were included as control. All stages of CKD patients attended at department of nephrology of Dhaka Medical College Hospital 
male or female, age within 18-to 80 years, gave consent to participate in the study were included as cases of the study. Age and sex matched person having no CKD and gave consent to participate in the study were included as control in the study. Persons aged less than 18 or more than 80 years, with malignant diseases, patients with acute renal failure and not giving consents were excluded from the study. Most of the CKD patients were admitted in nephrology department and some of them referred from other department of $\mathrm{DMCH}$, and some patients from the out patient department. All of the selected patients were undergone extensive clinical and physical evaluation. Routine laboratory investigations were done related to each case, i.e., urine R/M/E, Blood urea, $\mathrm{S}$ Creatinine, $\mathrm{S}$ Electrolytes, USG of KUB, S Cystatine C, DTPA renogram. CKD cases were diagnosed when the patients presented with elevated $\mathrm{S}$ Creatinine, abnormal USG of KUB, and/or abnormal GFR in DTPA renogram. Without CKD were diagnosed when the patients presented with normal $S$ Creatinine, normal USG of KUB, and/or normal GFR in DTPA renogram. From each participant 10 $\mathrm{ml}$ of blood samples were collected from the anticubital vein with minimum stasis and without frothing, using standard equipments (Sterile disposable $10 \mathrm{cc}$ syringe) and after taking aseptic precautions. Sample poured in clean labeled test tube for each patient and allows clotting. After 2030 minutes serum was separated by centrifuging at $3000 \mathrm{rpm}$ for 10 minutes. Then the serum was taken by using micropipettes in approximately labeled eppendoff. The tests were done in DMCH and BIRDEM. Creatinine reacts with alkaline picrate producing an orange red complex. The speed of absorbance change is proportional to the creatinine concentration. This test was done by Hitachi 912 (Germany) and reagents were also supplied by Hitachi. The study protocol was reviewed and approved by the ethical committee of Dhaka Medical College Hospital, Dhaka. The data was analysed by SPSS version 16 for window version. Mean value, range and SD were calculated. Linear regression analysis was done between $99 \mathrm{~m} \mathrm{Tc}$ DTPA clearance and serum Cystatin $\mathrm{C}$ and serum creatinine. To determine the diagnostic accuracy of Cystatin $\mathrm{C}$, serum creatinine, creatinine clearance calculated from the formula $C \& G$ and MDRD formula receiver operating characteristic (ROC) plots is constructed and analyzed.

Estimation of Cystatin C: The test is done in Immunology Department of BIRDEM, Shahbagh, Dhaka. Method: Nephelometry; Principle of Method: Polystyrene particle coated with specific antibodies to human Cystatin $\mathrm{C}$ are aggregated when mix with samples containing human Cystatin C. The aggregates scattered a beam of light passed through the sample. The intensity of the scattered light is proportional with a standard of known concentration. Procedure: At first I collected blood samples into the test tubes. Then 30 micro litre of blood was diluted automatically 1:100 with $\mathrm{N}$ diluent. Diluted sample was mixed with 40 micro litre reagent and supplementary reagent in reaction cuvette in the BN machine. Total reaction time was 6 minutes. After 6 minutes I collected result from the analyzer and the result was represented in milligram/litre.

Measurement of glomerular filtration rate: Because of the complexity of the Ci (Clearance of inulin) method and the inaccuracies of Pcr and $\mathrm{Ccr}$ as estimate of GFR, radionuclide methods have been developed. This includes ${ }^{125} \mathrm{I}$-iothalamate, ${ }^{99 \mathrm{~m}} \mathrm{TC}$ DTPA and ${ }^{51}$ CrEDTA. For each of these radio isotopes, renal clearance is prominently via filtration. Although a small amount of tubular secretion or re-absorption occurs, its magnitude is constant through the clinical range of GFR. Several clinical studies have shown that correlation between $\mathrm{Cm}$ and these isotope markers is excellent. Radionuclide studies of kidney can provide accurate determinations of kidney functions (either GFR or ERPF) using of some general methodologies. (a) Formal renal clearance studies measuring blood and urine $[\mathrm{C}=\mathrm{uv} / \mathrm{p}]$; (b) Single injection plasma clearances using disappearance curve techniques without urine sample and renal uptakes of radio nuclides detected by gamma camera without blood or urine sampling. DTPA renogram it is a dynamic study. One unit of DTPA kit is mixed radio active substance $\mathrm{Tc}^{99 \mathrm{~m}}$ (70-100 milicuri) and waited for 15 minutes for mixing. 5 milicuri radioactive mixtures were injected into the patient and take frame (image), total no. of frame is 87-90. After 40 frame one ample of frusemide were injected to the patients. Total study time was 30-35 minutes. Result of the test expressed as graph and \%.

GFR is calculated from the following formulas

\section{The Cockcroft and Gault formula}

$=(140$-age $)$ weight in $\mathrm{kg} / 72 \mathrm{x}$ serum creatinine (correction factor .85 in case of female) ${ }^{14}$.

2. Modification of diet in renal disease (MDRD) equation GFR

$$
\left.=186 x^{[S C R}\right]^{-1.154} \times \text { [age }{ }^{-0.203} \times[0.742 \text { if }
$$

pt is female] ${ }^{15}$. 
Staging of the patients with CKD: Staging of the patients with CKD were based on GFR. Stage I: Kidney damage with normal or high GFR when GFR $\left(\mathrm{ml} / \mathrm{min} / 1.73 \mathrm{~m}^{2}\right) \geq 90$; stage II: Kidney damage with slightly low GFR when GFR 60-89; stage III Moderately low GFR when GFR 30-59; stage IV: Severe low GFR when GFR 15-29 and stage V: Kidney failure when GFR $\left(\mathrm{ml} / \mathrm{min} / 1.73 \mathrm{~m}^{2}\right)$ $<15$ or dialysis.

\section{Results}

Purposively selected 100 participants were included in the study, among them 50 were CKD included in the study as cases and another 50 with age and sex matched were without CKD included as control. The present case control study was conducted in the department of Nephrology of Dhaka Medical College Hospital during the period of January 2009 to December 2009. In the present study total 100 respondents were included. Among them 50 were CKD patients and another 50 were without CKD.

Table 1: Characteristics of the study participants (age and gender matched)

\begin{tabular}{|c|c|c|c|}
\hline \multirow{2}{*}{ Variables } & \multicolumn{2}{|c|}{ Groups } & \multirow{2}{*}{$\begin{array}{c}\mathrm{P} \\
\text { value }\end{array}$} \\
\hline & CKD & $\begin{array}{l}\text { Without } \\
\text { CKD }\end{array}$ & \\
\hline \multicolumn{4}{|c|}{ Age (in year) } \\
\hline $25-35$ & $17(34.0)^{\#}$ & $17(34.0)$ & \\
\hline $35-45$ & $14(28.0)$ & $14(28.0)$ & \\
\hline $45-55$ & $19(38.0)$ & $19(38.0)$ & \\
\hline \multicolumn{4}{|l|}{ Gender } \\
\hline Male & $23(46.0)$ & $23(46.0)$ & \\
\hline Female & $27(54.0)$ & $27(54.0)$ & \\
\hline \multicolumn{4}{|l|}{ Weight (kg) } \\
\hline - $40-49$ & $04(08.0)$ & $00(0.0)$ & \\
\hline - $50-59$ & $35(70.0)$ & $08(16.0)$ & \\
\hline - $\geq 60$ & $11(22.0)$ & $42(84.0)$ & \\
\hline Mean \pm SD & $56.8 \pm 3.61$ & $62.24 \pm 3.85$ & $0.001^{*}$ \\
\hline \multicolumn{4}{|c|}{ Systolic BP (mmHg) } \\
\hline - $\leq 140$ & $37(74.0)$ & $42(84.0)$ & \\
\hline - $\quad>140$ & $13(26.0)$ & $08(16.0)$ & \\
\hline Mean \pm SD & $129.49 \pm 22.8$ & $126.36 \pm 16.0$ & $0.429^{*}$ \\
\hline \multicolumn{4}{|c|}{ Diastolic BP (mmHg) } \\
\hline - $\leq 90$ & $45(90.0)$ & $48(96.0)$ & \\
\hline - $>90$ & $05(10.0)$ & $02(04.0)$ & \\
\hline Mean \pm SD & $79.62 \pm 12.0$ & $79.36 \pm 9.3$ & $0.90^{*}$ \\
\hline
\end{tabular}

Table 1 shows the distribution of age by groups. In the CKD Group 17 (34.0\%) were in the age group of 25 to 35 years, $14(28.0 \%)$ were in the age group of 35 to 45 years and $19(38.0 \%)$ were in the age group of 45 to 55 years. In the without CKD Group $17(34.0 \%)$ were in the age group of 25 to 35 years, $14(28.0 \%)$ were in the age group of 35 to 45 years and $19(38.0 \%)$ were in the age group of 45 to 55 years. In the CKD group $23(46.0 \%)$ were male and $27(54.0 \%)$ were female. In the without CKD group $23(46.0 \%)$ were male and $27(54.0 \%)$ were female. In CKD 35 (70.0\%) were in the weight range of 50 to $59 \mathrm{~kg}$ followed by $11(22.0 \%)$ were in the weight range of more than $60 \mathrm{~kg}$ and only $4(8.0 \%)$ were in the weight range of 40 to $49 \mathrm{~kg}$. In without CKD group $42(84.0 \%)$ were in the more than $60 \mathrm{~kg}$ weight range and rest $8(16.0 \%)$ were in the 50 to $59 \mathrm{~kg}$. no respondent in the without CKD group was in the 40 to $49 \mathrm{~kg}$ weight range. Mean $\pm \mathrm{SD}$ of weight in CKD and without CKD groups were $56.82 \pm 3.61$ and $62.24 \pm 3.85 \mathrm{~kg}$ respectively. There is statistically significant difference in wt among the groups $(\mathrm{p}<0.05)$. Mean \pm SD of systolic blood pressure in CKD and without CKD groups were $129.49 \pm 22.8$ and $126.36 \pm 16.0 \mathrm{~mm}$ of $\mathrm{Hg}$ respectively. Mean \pm SD of diastolic blood pressure in CKD and without CKD groups were $79.62 \pm$ 12.0 and $79.36 \pm 9.3 \mathrm{~mm}$ of $\mathrm{Hg}$ respectively. There is no statistically significant difference in systolic and diastolic blood pressure among the groups $(\mathrm{p}>0.05)$

\section{Table 2: Distribution of Causes of the Diseases by Groups}

\begin{tabular}{|c|c|c|c|}
\hline \multirow[t]{2}{*}{ Variables } & \multicolumn{2}{|c|}{ Groups } & \multirow[t]{2}{*}{ P value } \\
\hline & CRD & $\begin{array}{l}\text { Without } \\
\text { CRDD }\end{array}$ & \\
\hline \multicolumn{4}{|c|}{ Glomerulonephritis } \\
\hline Present & $31(62.0)^{\#}$ & $0(0.0)$ & \\
\hline Absent & $19(38.0)$ & $50(100.0)$ & \\
\hline \multicolumn{4}{|c|}{ Hypertension } \\
\hline Present & $18(36.0)$ & $09(18.0)$ & \multirow[t]{2}{*}{0.070} \\
\hline Absent & $32(64.0)$ & $41(82.0)$ & \\
\hline \multicolumn{4}{|c|}{ Diabetes mellitus } \\
\hline Present & $11(22.0)$ & $06(12.0)$ & \multirow[t]{2}{*}{0.287} \\
\hline Absent & $39(78.0)$ & $44(88.0)$ & \\
\hline \multicolumn{4}{|c|}{ Obstructive uropathy } \\
\hline Present & $03(06.0)$ & $00(0.0)$ & \\
\hline Absent & $47(94.0)$ & $50(100.0)$ & \\
\hline
\end{tabular}

\#Figure within parenthesis indicates in percentage. ${ }^{*}$ Chi square test was done to measure the significance

Table 2 shows the distribution of causes of the diseases in CKD group and presence of HTN and DM without CKD group. In CKD group 31 $(62.0 \%)$ had glomerulonephritis, $18(36.0 \%)$ had HTN, 11 (22.0\%) had DM and $3(6.0 \%)$ had 
obstructive uropathy. In without CKD group 9 (18.0\%) had HTN, 6 (12.0\%) had DM. There is no statistically significant difference in HTN and DM among the groups $(\mathrm{p}>0.05)$.

Table 3: Stage of the patient with CKD based on renogram

\begin{tabular}{|l|c|c|}
\hline Stage & Frequency & Percent \\
\hline Stage III & 15 & $\mathbf{3 0 . 0}$ \\
\hline Stage IV & 29 & $\mathbf{5 8 . 0}$ \\
\hline Stage V & 06 & $\mathbf{1 2 . 0}$ \\
\hline Total & $\mathbf{5 0}$ & $\mathbf{1 0 0 . 0}$ \\
\hline
\end{tabular}

Table 3 shows the stages of patients with CKD. Out of 50 patients with CKD, $29(58.0 \%)$ were in the stage IV followed by $15(30.0 \%)$ were in the stage III and rest 6(12.0\%) were in the stage V.
Table 4 shows the mean distribution of biomarkers for diagnosis of chronic kidney disease. Mean \pm SD of Serum Creatinine in CKD and without CKD groups were $5.73 \pm 2.69$ and $0.85 \pm 0.11 \mathrm{mg} / \mathrm{dl}$ respectively. Mean \pm SD of Serum Cystatin C in CKD and without CKD groups were $3.59 \pm 1.21$ and $0.71 \pm 0.09 \mathrm{mg} / \mathrm{dl}$ respectively. Mean $\pm \mathrm{SD}$ of Creatinine clearance from MDRD formula in CKD and without CKD groups were $17.03 \pm 18.15$ and $91.56 \pm 14.12$ respectively. Mean \pm SD of Creatinine clearance from C\&G formula in CKD and without CKD groups were $18.57 \pm 16.54$ and $92.21 \pm 11.79$ respectively. There is statistically significant difference in Serum Creatinine, Serum Cystatin C, Creatinine clearance from MDRD formula and Creatinine clearance from $\mathrm{C} \& \mathrm{G}$ formula among the groups $(\mathrm{p}<0.05)$.

Table 4: Mean \pm SD of biomarkers for diagnosis of chronic kidney disease

\begin{tabular}{|c|c|c|c|}
\hline \multirow[t]{2}{*}{ Variables } & \multicolumn{2}{|c|}{ Groups } & \multirow[t]{2}{*}{ P value } \\
\hline & CKD & Without CKD & \\
\hline Serum Creatinine & $5.73 \pm 2.69$ & $0.85 \pm 0.11$ & 0.001 \\
\hline Serum Cystatin C & $3.59 \pm 1.21$ & $0.71 \pm 0.09$ & 0.001 \\
\hline $\begin{array}{l}\text { Creatinine clearance from MDRD } \\
\text { formula }\end{array}$ & $17.03 \pm 18.15$ & $91.56 \pm 14.12$ & 0.001 \\
\hline $\begin{array}{l}\text { Creatinine clearance from } \mathrm{C} \& \mathrm{G} \\
\text { formula }\end{array}$ & $18.57 \pm 16.54$ & $92.21 \pm 11.79$ & 0.001 \\
\hline
\end{tabular}

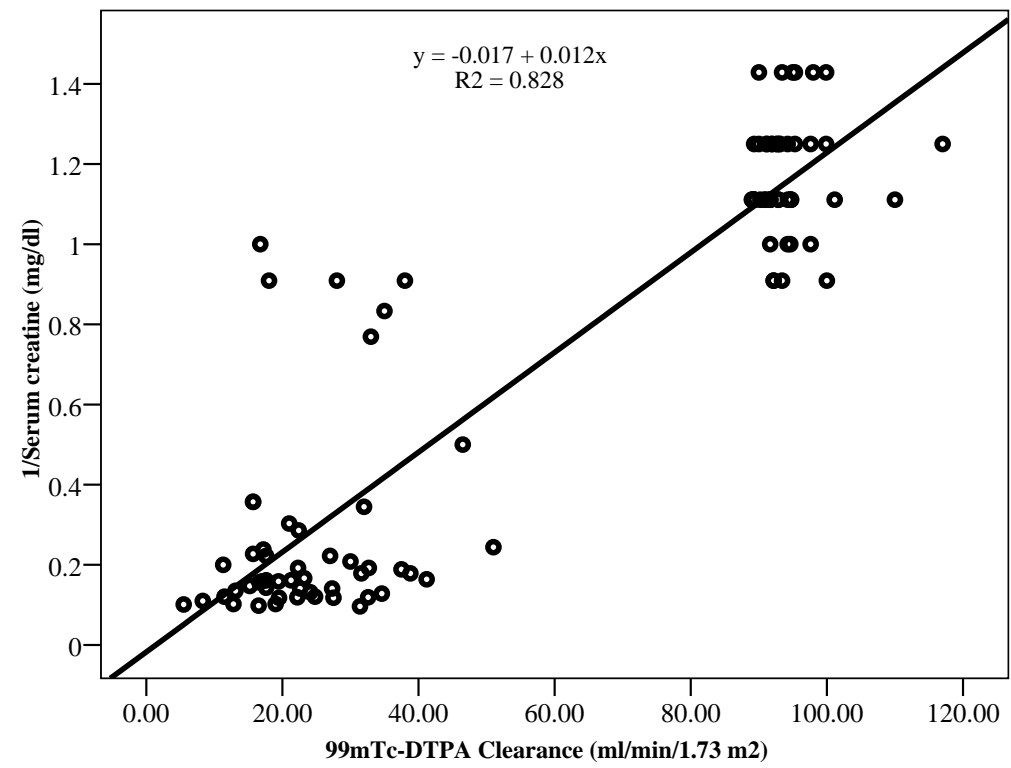

Figure 1: Linear regression plots between $99 \mathrm{mTc}-\mathrm{DTPA}$ clearance and serum creatinine $\square \mathrm{R}^{2}=0.828$; $\mathrm{p}<0.001$. 


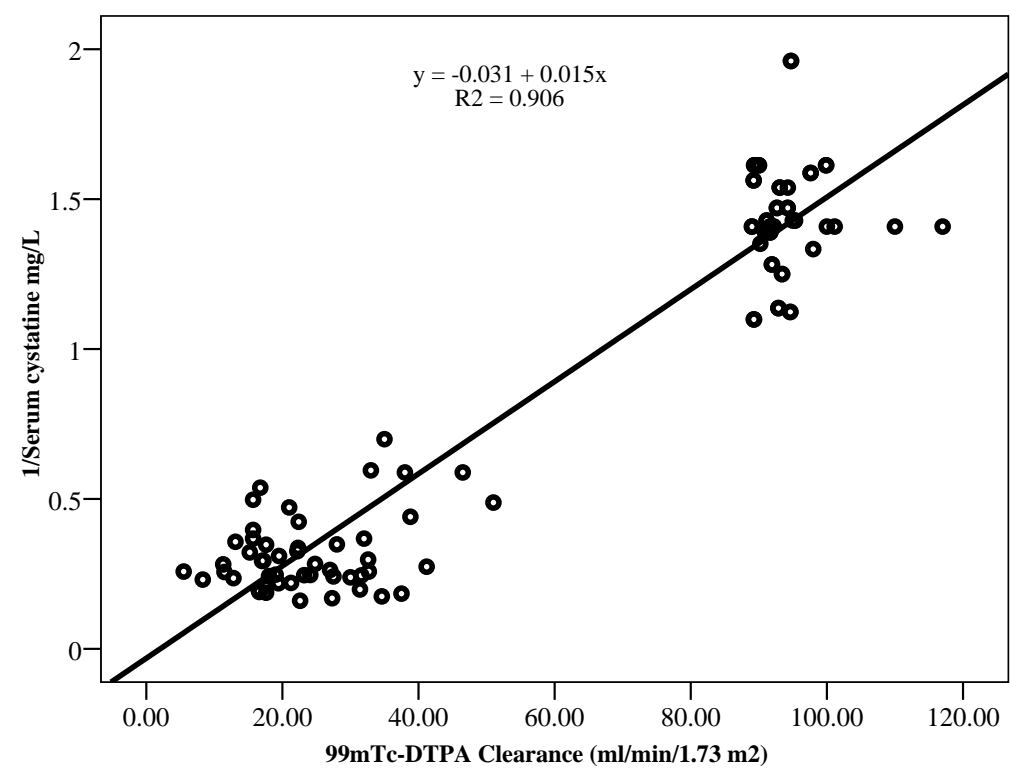

Figure 2: Linear regression plots between $99 \mathrm{mTc}$-DTPA clearance and serum Cystatin $\mathrm{C} \square \mathrm{R}^{2}=0.906$; $\mathrm{p}<0.001$

Figure 1 and 2 shows the linear regression analysis of $99 \mathrm{mTc}$-DTPA with reciprocal serum creatinine and reciprocal serum Cystatin C. Data analysis revealed that both serum creatinine and serum Table 5: Validity of test
Cystatin $\mathrm{C}$ shows positive correlation. However, $\mathrm{R}^{2}$ indicates that strength of association was more in serum Cystatin $\mathrm{C} \square \mathrm{R}^{2}=0.906 \square$ compared to serum creatinine $\square \mathrm{R}^{2}=0.828 \square$.

\begin{tabular}{|c|c|c|c|}
\hline Variables & $\begin{array}{l}\text { Area Under the } \\
\text { ROC Curve }\end{array}$ & Sensitivity & Specificity \\
\hline \multicolumn{4}{|l|}{ All patients } \\
\hline Cystatin C & 1.0 & 100.0 & 100.0 \\
\hline Creatinine & 0.995 & 88.0 & 100.0 \\
\hline$C \& G$ formula & 0.998 & 100.0 & 60.0 \\
\hline MDRD formula & 0.992 & 100.0 & 62.0 \\
\hline \multicolumn{4}{|l|}{ Male patients } \\
\hline Cystatin C & 1.0 & 100.0 & 100.0 \\
\hline Creatinine & 0.996 & 91.3 & 100.0 \\
\hline C\&G formula & 1.0 & 100.0 & 87.0 \\
\hline MDRD formula & 1.0 & 100.0 & 95.7 \\
\hline \multicolumn{4}{|l|}{ Female patients } \\
\hline Cystatin C & 1.0 & 100.0 & 100.0 \\
\hline Creatinine & 0.992 & 85.2 & 100.0 \\
\hline $\mathrm{C} \& \mathrm{G}$ formula & 0.999 & 100.0 & 40.7 \\
\hline MDRD formula & 0.995 & 100.0 & 29.6 \\
\hline
\end{tabular}

In all patients sensitivity of Cystatin $\mathrm{C}$ to diagnose CKD was $100.0 \%$ and specificity also100.0\%. Sensitivity of serum creatinine to diagnose CKD was $88.0 \%$ and specificity was $100.0 \%$. In male patients sensitivity of Cystatin $\mathrm{C}$ to diagnose CKD was $100.0 \%$ and specificity $100.0 \%$.
In male sensitivity of serum creatinine to diagnose CKD was $91.3 \%$ and specificity was $100.0 \%$. In female patients sensitivity of Cystatin $\mathrm{C}$ to diagnose CKD was $100.0 \%$ and specificity was $100.0 \%$. In female sensitivity of serum creatinine to diagnose CKD was $85.2 \%$ and specificity was $100.0 \%$. 


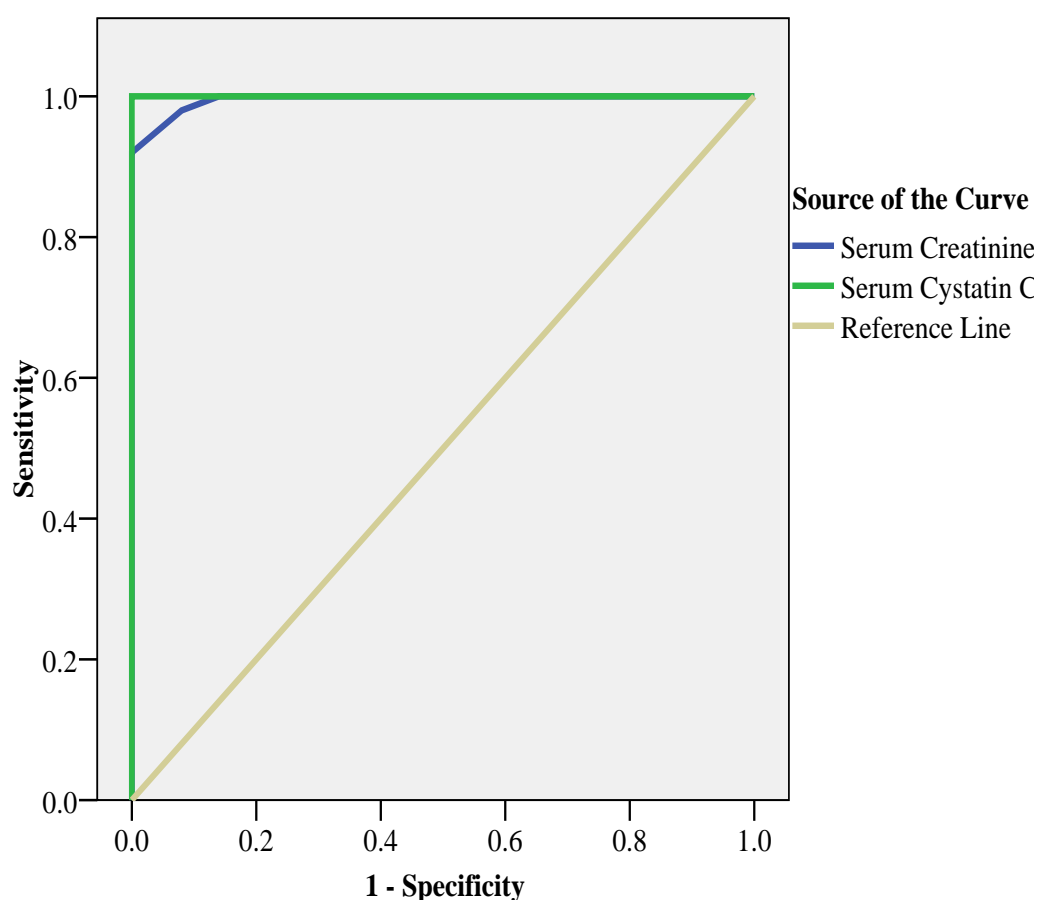

Figure 3: ROC curve

Diagnostic accuracy was determined as receiver operating characteristic (ROC) curve, suggesting that the area under the curve (AUC) of Cystacin C in the diagnosis of CKD was 1.0 and that of serum creatinine was 0.995 .

\section{Discussion}

The present case control study was conducted in the department of Nephrology of Dhaka Medical College Hospital during the period of January 2009 to December 2009 with the aim to find out the serum Cystatin $\mathrm{C}$ as diagnostic markers of chronic kidney disease. In the present study total 100 respondents were included. Among them 50 were CKD patients and another 50 were without CKD. It was an age and sex matched study. Patients other than CKD attending same hospital were selected as control.

In the present study in CKD Group 17 (34.0\%) were in the age group of 25 to 35 years, 14 $(28.0 \%)$ were in the age group of 35 to 45 years and $19(38.0 \%)$ were in the age group of 45 to 55 years. In the without CKD Group 17 (34.0\%) were in the age group of 25 to 35 years, $14(28.0 \%)$ were in the age group of 35 to 45 years and 19 $(38.0 \%)$ were in the age group of 45 to 55 years. In the CKD group $23(46.0 \%)$ were male and 27 $(54.0 \%)$ were female. In the without CKD group $23(46.0 \%)$ were male and $27(54.0 \%)$ were female. It is age and sex matched study. In CKD $35(70.0 \%)$ were in the weight range of 50 to $59 \mathrm{~kg}$ followed by $11(22.0 \%)$ were in the weight range of more than $60 \mathrm{~kg}$ and only $4(8.0 \%)$ were in the weight range of 40 to $49 \mathrm{~kg}$. In without CKD group $42(84.0 \%)$ were in the more than $60 \mathrm{~kg}$ weight range and rest $8(16.0 \%)$ were in the 50 to $59 \mathrm{~kg}$. no respondent in the without CKD group was in the 40 to $49 \mathrm{~kg}$ weight range. Mean \pm SD of weight in CKD and without CKD groups were $56.82 \pm 3.61$ and $62.24 \pm 3.85 \mathrm{~kg}$ respectively. There is statistically significant difference in wt among the groups $(p<0.05)$. Mean \pm SD of systolic blood pressure in CKD and without CKD groups were $129.49 \pm 22.8$ and $126.36 \pm 16.0 \mathrm{~mm}$ of $\mathrm{Hg}$ respectively. Mean \pm SD of diastolic blood pressure in CKD and without CKD groups were $79.62 \pm 12.0$ and $79.36 \pm 9.3 \mathrm{~mm}$ of $\mathrm{Hg}$ respectively. There is no statistically significant difference in systolic blood pressure and diastolic blood pressure among the groups ( $\mathrm{p}>0.05)$.

In presents study among CKD group 31 (62.0\%) had glomerulonephritis, 18 (36.0\%) had HTN, 11 (22.0\%) had DM and $3(6.0 \%)$ had obstructive uropathy. In without CKD group $9(18.0 \%)$ had HTN, 6 (12.0\%) had DM. Salman et al. $(2015)^{16}$ in their study reported the most frequent attributable cause of CKD was diabetic nephropathy (44.9\%), followed by hypertension $(24.2 \%)$, obstructive uropathy $(9.2 \%)$, glomerulonephritis $(6.7 \%)$. They also reported CKD was unknown in $9.4 \%$ of their cases. In the present study out of 50 patients with CKD, 29 (58.0\%) were in the stage IV followed by $15(30.0 \%)$ were in the stage III and rest $6(12.0 \%)$ 
were in the stage V. Font et al. (2009) ${ }^{12}$ studied 52 non diabetic patients where 38 were men and 14 were female with mean age 49 years. In their study CKD in stage III were 22, in stage IV were 25 and in stage $\mathrm{V}$ were 5.

In the present study the mean $\pm \mathrm{SD}$ of Serum Creatinine in CKD and without CKD groups were $5.73 \pm 2.69$ and $0.85 \pm 0.11 \mathrm{mg} / \mathrm{dl}$ respectively. Mean \pm SD of Serum Cystatin C in CKD and without CKD groups were $3.59 \pm 1.21$ and $0.71 \pm 0.09 \mathrm{mg} / \mathrm{dl}$ respectively. Mean $\pm \mathrm{SD}$ of Creatinine clearance from MDRD formula in CKD and without CKD groups were $17.03 \pm 18.15$ and $91.56 \pm 14.12$ respectively. Mean \pm SD of Creatinine clearance from $\mathrm{C} \& \mathrm{G}$ formula in $\mathrm{CKD}$ and without CKD groups were $18.57 \pm 16.54$ and $92.21 \pm 11.79$ respectively. There is statistically significant difference in Serum Creatinine, Serum Cystatin C, Creatinine clearance from MDRD formula and Creatinine clearance from $C \& G$ formula among the groups $(p<0.05)$. Shimizu-Tokiwa et $\mathrm{al}^{17}$ studied to determine the relationship between the levels of serum Cystatin $\mathrm{C}$ or creatinine (s-Cr) and the grade of creatinine clearance $(\mathrm{CCr})$ in patients with various glomerular diseases. In their study, an increase of serum Cystatin C levels occurred earlier than that of s-Cr in various glomerular diseases. In the present study highest number of CKD cases of the present study presented with glomerulonephritis. Raised level of Cystatin C found in patients with CKD due to glomerulonephritis. Villa et $\mathrm{al}^{18}$ studied to analyze the utility of serum Cystatin $\mathrm{C}$ as a marker of renal function in these patients. In their study serum creatinine, serum Cystatin C and 24-hour creatinine clearance $(\mathrm{CCr})$ were determined in 50 critically ill patients (age 21-86 years). They reported serum creatinine, serum Cystatin $\mathrm{C}$ and $\mathrm{CCr}$ (mean \pm standard deviation [range]) were $1.00 \pm 0.85 \mathrm{mg} / \mathrm{dl} \quad(0.40-5.61 \mathrm{mg} / \mathrm{dl}), \quad 1.19 \pm 0.79$ $\mathrm{mg} / \mathrm{l}(0.49-4.70 \mathrm{mg} / \mathrm{l})$, and $92.74 \pm 52.74 \mathrm{ml} / \mathrm{min}$ per $1.73 \mathrm{~m} 2(8.17-233.21 \mathrm{ml} / \mathrm{min}$ per $1.73 \mathrm{~m} 2)$, respectively. Font et al. (2009) ${ }^{12}$ studied 52 nondiabetic patients ( 38 men, mean age 49 years) with CKD stage 3 (22), 4 (25) or 5 (5). In their study the mean Cystatin $\mathrm{C}$ levels were $2.35 \pm 0.9 \mathrm{mg} / \mathrm{l}$. Finney et $\mathrm{al}^{13}$ studied blood sample from 309 healthy blood donors to determine an adult reference range of creatinine and Cystatin C concentrations. The $95 \%$ reference intervals for creatinine, predicted creatinine clearance and Cystatin $\mathrm{C}$ for all blood donors, regardless of gender, were $68-118 \mu \mathrm{mol} / \mathrm{L}, 58-120 \mathrm{ml} / \mathrm{min} / 1.73$ $\mathrm{m} 2$ and $0 \cdot 51-0.98 \mathrm{mg} / \mathrm{L}$, respectively.
Linear regression plots between 99mTc-DTPA clearance and serum creatinine $\square \mathrm{R}^{2}=0.828$; $\mathrm{p}<0.001$. Linear regression plots between $99 \mathrm{mTc}-$ DTPA clearance and serum Cystatin $C$ $\mathrm{R}^{2}=0.906 ; \mathrm{p}<0.001$. Burkhardt et $\mathrm{al}^{19}$ in a crosssectional study analyzed the secondary of data to evaluate the diagnostic efficiency of Cystatin $\mathrm{C}$ as a marker of the glomerular filtration rate in the elderly. In their study 30 patients (15 male, 15 female, mean age $75.4 \pm 7.1$ years) were included and among them 12 patients had a reduced glomerular filtration rate $\left(<70 \mathrm{ml} / \mathrm{min} / 1.73 \mathrm{~m}^{2}\right)$. in their study the mean values were $88.4 \mu \mathrm{mol} / 1$ $( \pm 27.7)$ for serum creatinine, $1.57 \mathrm{mg} / \mathrm{l}( \pm 0.34)$ for Cystatin $\mathrm{C}$ and $88.7 \mathrm{ml} / \mathrm{min} / 1.73 \mathrm{~m}^{2}( \pm 34.6)$ for inulin clearance. Maximum efficiency was 0.73 for serum creatinine (cut-off limit $82 \mu \mathrm{mol} / \mathrm{l}$ ), 0.67 for Cystatin C (cut-off limit $1.63 \mathrm{mg} / \mathrm{l}$ ) and 0.8 for Cockcroft and Gault estimation (cut-off limit 54 $\mathrm{ml} / \mathrm{min} / 1.73 \quad \mathrm{~m}^{2}$ ). A receiver operating characteristics (ROC) analysis did not show any differences between the various methods. Burkhardt et al. (2002) $)^{19}$ in their study concluded that Cystatin $\mathrm{C}$ in serum may not improve the diagnostic efficiency in detecting a reduced glomerular filtration rate in the elderly and normal ranges for serum creatinine in the elderly might need to be adjusted.

During the last century, SCr has been the most used biomarker to screen and diagnose kidney disease. SCr however has several limitations and should be utilized only in estimating equations ${ }^{20}$. Concentration of serum Cystatin $\mathrm{C}$ is not affected by gender, age, race, protein intake, and muscle mass, unlike serum creatinine and GFR decreases, Cystatin $\mathrm{C}$ level begins to rise proportionately ${ }^{21}$. In the present study we found sensitivity of Cystatin $\mathrm{C}$ to diagnose CKD was $100.0 \%$ and specificity also100.0\%. Sensitivity of serum creatinine to diagnose CKD was $88.0 \%$ and specificity was $100.0 \%$. In male patients sensitivity of Cystatin C to diagnose CKD was $100.0 \%$ and specificity $100.0 \%$. In male sensitivity of serum creatinine to diagnose CKD was $91.3 \%$ and specificity was $100.0 \%$. In female patients sensitivity of Cystatin $\mathrm{C}$ to diagnose CKD was $100.0 \%$ and specificity was $100.0 \%$. In female sensitivity of serum creatinine to diagnose CKD was $85.2 \%$ and specificity was $100.0 \%$. Although some studies like Stickle et al. (1998) ${ }^{22}$, Spanaus et al. (2010) ${ }^{23}$, Ribichini et al (2012) ${ }^{24}$ have showed different results, several previous studies by Grubb et al $(1985)^{25}$, Simonsen et al. (1985) ${ }^{26}$, Harmoinen et al $(1999)^{27}$, Kyhse-Andersen et $\mathrm{al}^{28}$, Newman et $\mathrm{al}^{29}$, Coll et $\mathrm{al}^{30}$ have demonstrate the superiority of Cystatin $\mathrm{C}$ as a measure of GFR thus diagnosis of 
CKD in comparison to serum creatinine. A metaanalysis by Dharnidharka et $\mathrm{al}^{31}$ also reported the superiority of Cystatin $\mathrm{C}$ as a measure of GFR thus diagnosis of $\mathrm{CKD}$ in comparison to serum creatinine.

Diagnostic accuracy was determined as receiver operating characteristic (ROC) curve, suggesting that the area under the curve (AUC) of Cystatin C in the diagnosis of CKD was 1.0 and that of serum creatinine was $0.995(\mathrm{p}<0.05)$. Villa et $\mathrm{al}^{18}$ studied to analyze the utility of serum Cystatin $\mathrm{C}$ as a marker of renal function in these patients. Their results showed that serum Cystatin $\mathrm{C}$ correlated better with GFR than did creatinine (1/Cystatin C versus $\mathrm{CCr}: \mathrm{r}=0.832, P<0.001 ; 1 /$ creatinine versus $\mathrm{CCr}$ : $\mathrm{r}=0.426, P=0.002)$. Cystatin $\mathrm{C}$ was diagnostically superior to creatinine (area under the curve [AUC] for Cystatin C 0.927, 95\% confidence interval 86.1-99.4; AUC for creatinine $0.694,95 \%$ confidence interval 54.1-84.6). Only five $(20 \%)$ of these 25 patients had elevated serum creatinine, whereas $76 \%$ had elevated serum Cystatin $\mathrm{C}$ levels $(P=0.032)$. From their study they concluded that Cystatin $\mathrm{C}$ is an accurate marker of subtle changes in GFR, and it may be superior to creatinine when assessing this parameter in clinical practice in critically ill patients. Gokku et $\mathrm{al}^{10}$ in a study investigated the relationship between Cyst $\mathrm{C}$ and creatinine (CR) in renal disease patients. They found a strong correlation between Cyst $\mathrm{C}$ and $\mathrm{CR}(P=0.001, r=$ 0.764 and $P=0.0001, r=0.888$, respectively) in prehemodialysis (pre-HD) and kidney transplantation (Tx-kidney), whereas there was a weak correlation in continuous ambulatory peritoneal dialysis (CAPD) $(P=0.05, r=0.535)$. They concluded that serum Cyst $\mathrm{C}$ may be considered as a sensitive predictive parameter for reduced GFR. In the present study we found Cyst $\mathrm{C}$ raised in patients with decreased GFR. Filler et $\mathrm{al}^{32}$ in their study showed that there was a positive correlation between 51Cr-EDTA clearance and the Cys-C $\quad(r=0.64, \quad p<0.0001), \quad$ beta2-MG $(r=0.59$ $\mathrm{p}<0.0001)$, and the height/ creatinine ratio $(\mathrm{r}=0.55$, $\mathrm{P}<0.0001)$, and height/Creatinine ratio $(\mathrm{r}=0.73$, $\mathrm{Pz}<0.0001)$. Le Bricon et $\mathrm{a}^{33}$ showed that plasma concentration of Cystatin C significantly decreased during first week ( $-44 \%$ vs. $-29 \%$ for creatinine). Plasma Cystatin C correlates with plasma Creatinine $(\mathrm{r}=0.741 ; \mathrm{P}<0.0001)$ and the reciprocal of creatinine clearance estimated by CockcroftGault formula $(r=0.882, \mathrm{P}<0.001)$. All three cases the increase in plasma Cystatin $\mathrm{C}$ values was more prominent than that of creatinine. Coll et $\mathrm{al}^{34}$ in their study showed Serum Cystatin C level a greater sensitivity $(93.4 \%)$ than serum creatinine level (86.8\%). Also, serum Cystatin C showed the greatest proportion of increased values in patients with impaired renal function (100\%) compared with serum creatinine level $(92.15 \%)$. Serum Cystatin $\mathrm{C}$ levels started to increase to greater than normal values when GFR was $88 \mathrm{~mL} / \mathrm{min} / 1.73 \mathrm{~m}^{2}$, whereas serum creatinine level began to increase when GFR was $75 \mathrm{~mL} / \mathrm{min} / 1.73 \mathrm{~m}^{2}$. It suggest the measurement of serum Cystatin $\mathrm{C}$ may be useful to estimate GFR, especially to detect mild reductions in GFR, and therefore may be important in the detection of early renal insufficiency in a variety of renal diseases for which early treatment is critical.

\section{Conclusion}

The simplicity of serum Cystatin $\mathrm{C}$ detection and its reasonable cost suggest that this test may soon replace $\mathrm{Ccr}$ as the biochemical marker of choice for monitoring GFR in routine practice. Cystatin C proved more reliable than creatinine and was comparable to plasma creatinine and CockcroftGault estimation. It has a higher correlation with the "gold standard" test than plasma creatinine and the Cockcroft -Gault estimation. Cystatin $\mathrm{C}$ has advantages over routine clinical measure of renal function, being more accurate than plasma creatinine and the cockcroft Gault estimation of creatinine clearance. Cystatin $\mathrm{C}$ can be used in clinical considerations with varying degrees of kidney function. Cystatin $\mathrm{C}$ may detect decreases in GFR that are not evident with serum creatininebased measurements. From this study it can be concluded that Cystatin $\mathrm{C}$ is a reliable marker of renal function. Serum Cystatin $\mathrm{C}$ had higher diagnostic accuracy with high sensitivity and specificity to detect renal function. Cystatin $\mathrm{C}$ had same sensitivity in female and male but Cystatin $\mathrm{C}$ had no significant difference in respect to diagnostic accuracy with creatinine.

\section{References}

1. Vejakama $\mathrm{P}$, Ingsathit $\mathrm{A}$, Attia $\mathrm{J}$, Thakkinstian $\mathrm{A}$. Epidemiological Study of Chronic Kidney Disease Progression: A Large-Scale Population-Based Cohort Study. Medicine (Baltimore) 2015; 94(4): e475

2. National Kidney Foundation. K/DOQI Clinical practice guidelines for chronic kidney disease: Evaluation, classification, and stratification. Am J Kidney Dis 2002, 39: S1-S266

3. Al-Hisnawi RAAA and Salih H. A study of some biochemical changes in patients with chronic renal failure undergoing hemodialysis. Int.J.Curr.Micro biol.App.Sci 2014;3(5): 581-586

4. Fored CM, Ejerblad E, Fryzek JP, Lambe M, Lindblad $\mathrm{P}$, Nyren O, Elinder C-G. Socio-economic status and chronic renal failure: a population-based case-control 
study in Sweden. Nephrology Dialysis Transplantation 2003:18(1);82-88

5. Goddard J, Turner AN, Cumming AD, Stewart LH. Kidney and urinary tract disease. In Davidson's Principles and Practice of Medicine. Eds: Boon NA, Colledge NR, Walker BR, Hunter JAA. $20^{\text {th }}$ edition. Edinburgh Churchill Livingstone 2006; 17 :485-491

6. Gowda S, Desai PB, Kulkarni SS, Hull VV, Math AAK, Vernekar SN. Markers of renal function tests. North Am J Med Sci 2010; 2:170-173

7. Stevens LA, Coresh J, Schmid CH, Feldman HI, Froissart M, Kusek J, et al. 2008. Estimating GFR using Serum Cystatin C Alone and in Combination with Serum Creatinine: A Pooled Analysis of 3418 Individuals with CKD. Am J Kidney Dis 2008; 51(3):395-406

8. Hojs R, Bevc S, Ekart R, Gorenjak M, Puklavec L. Serum Cystatin $\mathrm{C}$ as an Endogenous Marker of Renal Function in Patients with Chronic Kidney Disease. Renal Failure 2008; 30(2):181-186

9. Krishnamurthy N, Arumugasamy K, Anand U, Anand CV, Aruna V, Venu G, Gayathri R. Effect of hemodialysis on circulating cystatin c levels in patients with end stage renal disease. Indian Journal of Clinical Biochemistry 2010; 25(1): 43-46

10. Gokku CA, Ozden TA, Gul H, Y1ldız A. Relationship between plasma Cystatin $\mathrm{C}$ and creatinine in chronic renal diseases and Tx-transplant patients. Clinical Biochemistry 2004; 37(2): 94-97

11. Obrenovi R, Petrovi D, Majki-Singh N, Trbojevi J, Stojimirovi B. Influence of proteinuria on Cystatin $\mathrm{C}$ serum concentration in patients with primary glomerulonephritis. Jugoslov Med Biohem 2006; 25:2125

12. Font R, Prats M, Vea AM, Gutiérrez C, Bardaji A, Lalana M, Marsillach J, Camps J. Is there a relationship between cystatin $\mathrm{C}$ and inflammatory status, oxidative stress and other cardiovascular risk factors in nondiabetic patients with chronic kidney disease? Nefrologia 2009; 29(3): 228-235

13. Finney H, Newman DJ, Price CP. Adult reference ranges for serum cystatin $\mathrm{C}$, creatinine and predicted creatinine clearance. Ann Clin Biochem 2000; 37:49-59

14. Cockcroft DW and Gault MH. Prediction of creatinine clearance from serum creatinine. Nephron 1976;16(1):31-41

15. Pendse SS and Singh A. Approach to patients with chronic kidney disease, stages 1-4. In Handbook of dialysis. Daugirdas JT, Blake PG, Ing TS edts. $1^{\text {st }}$ edition, 2007, New Delhi, Wolters Kulwer (India) Pvt. Ltd.: 1-13

16. Salman M, Khan AH, Adnan AS, Sulaiman SAS, Hussain K, Shehzadi N, Jummaat F. Attributable causes of chronic kidney disease in adults: a five-year retrospective study in a tertiary-care hospital in the northeast of the Malaysian Peninsula. Sao Paulo Med J 2015; 133(6):502-9

17. Shimizu-Tokiwa A, Kobata M, Io H, Kobayashi N, Shou I, Funabiki K, et al. Serum Cystatin C Is a More Sensitive Marker of Glomerular Function than Serum Creatinine. Nephron 2002; 92:224-226

18. Villa P, Jimenez M, Soriano MC, Manzanares J, Casasnovas P. Serum cystatin C concentration as a marker of acute renal dysfunction in critically ill patients. Critical Care 2005; 9:R139-R143

19. Burkhardt H, Bojarsky G, Gladisch R. Diagnostic Efficiency of Cystatin C and Serum Creatinine as Markers of Reduced Glomerular Filtration Rate in the Elderly. Clinical Chemistry and Laboratory Medicine 2002; 40(11):1135-1138
20. Lopez-Giacoman S and Madero $M$. Biomarkers in chronic kidney disease, from kidney function to kidney damage. World J Nephrol 2015; 4(1): 57-73

21. Murty MSN, Sharma UK, Pandey VB, Kankare SB. Serum cystatin $\mathrm{C}$ as a marker of renal function in detection of early acute kidney injury. Indian J Nephrol 2013; 23(3): 180-183

22. Stickle D, Cole B, Hock K, Hruska KA, Scott MG. Correlation of plasma concentrations of cystatin $\mathrm{C}$ and creatinine to inulin clearance in a pediatric population. Clin Chem 1998;44:1334-1338

23. Spanaus KS, Kollerits B, Ritz E, Hersberger M, Kronenberg F, von Eckardstein A. Serum creatinine, cystatin $\mathrm{C}$, and beta-trace protein in diagnostic staging and predicting progression of primary nondiabetic chronic kidney disease. Clin Chem. 2010;56:740-749

24. Ribichini F, Gambaro G, Graziani MS, Pighi M, Pesarini G, Pasoli P, Anselmi M, Ferrero V, Yabarek T, Sorio A, Rizzotti P, Lupo A, Vassanelli C. Comparison of serum creatinine and cystatin $\mathrm{C}$ for early diagnosis of contrastinduced nephropathy after coronary angiography and interventions. Clin Chem 2012;58:458-464

25. Grubb A, Simonsen O, Sturfelt G, Truedsson L, Thysell H. Serum concentration of cystatin C, factor D and beta 2-microglobulin as a measure of glomerular filtration rate. Acta Med Scand 1985;218:499-503

26. Simonsen O, Grubb A, Thysell H. The blood serum concentration of cystatin C (gamma-trace) as a measure of the glomerular filtration rate. Scand J Clin Lab Invest. 1985;45:97-101

27. Harmoinen AP, Kouri TT, Wirta OR, Lehtimaki TJ, Rantalaiho V, Turjanmaa VM, Pasternack AI. Evaluation of plasma cystatin $\mathrm{C}$ as a marker for glomerular filtration rate in patients with type 2 diabetes. Clin Nephrol 1999;52:363-370

28. Kyhse-Andersen J, Schmidt C, Nordin G, Andersson B, Nilsson-Ehle P, Lindstrom V, Grubb A. Serum cystatin $\mathrm{C}$, determined by a rapid, automated particle-enhanced turbidimetric method, is a better marker than serum creatinine for glomerular filtration rate. Clin Chem 1994:40:1921-1926

29. Newman DJ, Thakkar H, Edwards RG, Wilkie M, White T, Grubb AO, Price CP. Serum cystatin C measured by automated immunoassay: a more sensitive marker of changes in GFR than serum creatinine. Kidney Int 1995;47:312-318

30. Coll E, Botey A, Alvarez L, Poch E, Quinto L, Saurina A, Vera M, Piera C, Darnell A. Serum cystatin C as a new marker for noninvasive estimation of glomerular filtration rate and as a marker for early renal impairment. Am J Kidney Dis 2000;36:29-34

31. Dharnidharka VR, Kwon C, Stevens G. Serum cystatin C is superior to serum creatinine as a marker of kidney function: a meta-analysis. Am J Kidney Dis 2002;40:221-226

32. Filler G, Priem F, Vollmer I, Gellermann J, Jung K. Diagnostic sensitivity of serum cystatin for impaired glomerular filtration rate. Pediatric Nephrology 1999;13(6):501-505

33. Le Bricon T, Thervet E, Benlakehal M, Bousquet B, Legendre C, Erlich D. Changes in plasma cystatin C after transplantation and acute rejection in adults. Clin Chem 1999; 45(12): 2243-2249

34. Coll E, Botey A, Alvarez L, Poch E, Quinto L, Saurina $A$, et al. Serum cystain $C$ as a new marker for noinvasive estimation of glomerular filtration rate and as a marker for early renal impairment. Am J Kidney Dis 2000;36(1):29-34 